\title{
Selective and age-dependent changes of prostaglandin E-2 in the epididymis and vas deferens of the rat
}

\author{
K. Gerozissis and F. Dray \\ Unité de Radioimmunologie Analytique, Institut Pasteur 28, rue du Dr. Roux, \\ 75724-Paris cédex 15, France
}

The biosynthesis of prostaglandins (PGs) occurs in the testes and seminal vesicles of various animal species (Carpenter, Manning \& Wiseman, 1971; Christ \& Van Dorp, 1972; Ellis, 1972). Theeffects of PGs on the contractility of the testicular capsule, epididymis and vas deferens in vitro and the effects of PG administration on the transport of spermatozoa suggest a possible role of PGs in the physiology of the male reproductive system (Davis, Langford \& Kirby, 1970; Hafs, Louis \& Stellflung, 1974).

PGs are present in high concentrations in the seminal plasma of man and sheep and at much lower levels in the seminal plasma of other species (Eliasson, 1959). Information on the PG content of accessory sex tissues in adult males is scanty and, in some instances, contradictory (Jouvenaz, Nugteren, Beerthuis \& Van Dorp, 1970; Decuminsky \& Mercury, 1971; Tan \& Privett, 1972). Failure to prevent synthesis and degradation of PGs in vitro may explain the high variability of the values (Jouvenaz et al., 1970). The present study was of the changes of PG content in the different parts of the rat genital tract at different ages.

\section{Methods}

The rats were of the Wistar strain and were killed by a sharp blow on the head. Within $90 \pm 20$ sec one tissue from each rat was removed and plunged into liquid nitrogen. At the time of analysis, the frozen tissue was weighed and while still frozen homogenized in a Potter homogenizer ( $25 \mathrm{sec}$, $4000 \mathrm{rev} / \mathrm{min}$ ) in ice-cold phosphate-buffered saline (pH 7.4) containing $0.1 \%(\mathrm{w} / \mathrm{v})$ glucose, $0.02 \%$ $(\mathrm{w} / \mathrm{v})$ aspirin and a known amount of radiolabelled $\mathrm{PG}$ for recovery estimation. The homogenate was immediately acidified with citric acid and the PGs (E-1, E-2, F-1 $\alpha$ and F-2 $\alpha$ ) were extracted with cyclohexane: ethyl acetate $(1: 1 \mathrm{v} / \mathrm{v})$, purified and separated on silicic acid columns and measured by radioimmunoassay. Identical conditions were used for all tissues and semen. The specificity and sensitivity of the assay have been described (Dray, Charbonnel \& Maclouf, 1975; Maclouf, Andrieu \& Dray, 1975). A specific PGF-1 $\alpha$ antiserum raised in rabbits was used for PGF-1 $\alpha$ measurements. It had an association constant $\left(K_{\alpha}\right)$ of $7.2 \times 10^{-9} \mathrm{M}$ and cross-reactivity of $6 \%$ with PGF- $2 \alpha$. The displacement of $\left[{ }^{3} \mathrm{H}\right]$ PGF- $1 \alpha$ (sp. act. $90 \mathrm{Ci} / \mathrm{mmol}$ ), was $84 \%$ and $50 \%$ by 10 and $42 \mathrm{pg}$ PGF- $1 \alpha$ respectively (unpublished results). Analysis of variance was used for statistical evaluation.

Preliminary studies had shown that if the tissue was not frozen until $4 \mathrm{~min}$ after death, the values of PGE-2 and PGF-2 $\alpha$ were increased by a factor of $2-5$ times. Similar increases were found if the tissue was allowed to thaw before homogenization.

\section{Results and discussion}

The content of PGE-1 and PGF-1 $\alpha$ was less than that of PGE- 2 and PGF- $2 \alpha$, i.e. $\leqslant 20 \%$ and often undetectable in testis, epididymis, vas deferens, coagulating glands and prostate and $30-50 \%$ in the seminal vesicles. The levels of all four PGs in the vesicular fluid of 90-day-old rats were below the limit of detection ( $<0.02 \mathrm{ng} / 0.1 \mathrm{ml}, 3$ rats). The mean ( \pm S.E.M.) concentrations (in $\mathrm{ng} / \mathrm{g}$ tissue) of PGE-2 and PGF- $2 \alpha$ in adult rats were highest in vas deferens (2962 \pm 1270 and $275 \pm 93$ respectively, 7 rats) and low ( 3 rats/group) in seminal vesicles $(1 \cdot 3 \pm 0 \cdot 3$ and $5 \cdot 0 \pm 0 \cdot 9)$, coagulating glands $(2 \cdot 7 \pm 0 \cdot 1$ and $4 \cdot 2 \pm 0.5)$ and prostate $(1 \cdot 2 \pm 0.5$ and $0.8 \pm 0.6)$ and still lower in decapsulated testis $(0.05 \pm 0.02$ and $0 \cdot 10 \pm 0 \cdot 02,7$ rats). Throughout maturation (Days 26-90) there was no significant variation $(P>0.5)$ in the concentration of either PG in the decapsulated testes (PGE-2, $0.05 \pm 0.02 ;$ PGF-2 $\alpha$, $0 \cdot 10 \pm 0.02,21$ rats). This observation is compatible with the findings of Carpenter (1971) that 
Table 1. Changes (mean \pm S.E.M.) in prostaglandin content $(\mathrm{ng} / \mathrm{g})$ in the epididymis and vas deferens of rats of different ages

\begin{tabular}{|c|c|c|c|c|c|}
\hline \multirow[b]{3}{*}{ Epididymis } & \multicolumn{5}{|c|}{ Age (days) } \\
\hline & \multirow[t]{2}{*}{$26-33$} & \multirow[t]{2}{*}{$34-38$} & \multirow[t]{2}{*}{$40-50$} & \multirow[t]{2}{*}{$55-65$} & $90-113$ \\
\hline & & & & & \\
\hline No. of rats & 22 & 19 & 14 & 14 & 8 \\
\hline PGE-2 & $39 \pm 14$ & $175 \pm 65^{*}$ & $16 \pm 9$ & $25 \pm 20$ & $7 \pm$ \\
\hline PGF-2 $\alpha$ & $33 \pm 12$ & $34 \pm 11$ & $44 \pm 18$ & $61 \pm 49$ & $54 \pm 26$ \\
\hline \multicolumn{6}{|l|}{ Vas deferens } \\
\hline No. of rats & 12 & 18 & 9 & 10 & 7 \\
\hline PGE-2 & $495 \pm 183$ & $1088 \pm 390 \dagger$ & $1045 \pm 370$ & $2077 \pm 448 \dagger$ & $2962 \pm 1270$ \\
\hline PGF-2 $\alpha$ & $461 \pm 112$ & $147 \pm 66 \ddagger$ & $175 \pm 81 \ddagger$ & $118 \pm 56 t$ & $275 \pm 93 \ddagger$ \\
\hline
\end{tabular}

* Significantly different $(P<0.01)$ from other groups in that row (Student's $t$ test).

$\uparrow$ Significantly different $(P<0.01)$ from preceding group.

$\ddagger$ Significantly different $(P<0.01)$ from value for 26-33-day-old rats, but not from each other $(P>0.05)$.

Table 2. Changes (mean \pm S.E.M.) in the prostaglandin content $(\mathrm{ng} / \mathrm{g})$ of the rat epididymis between 30 and 40 days: of age

\begin{tabular}{lcccccc}
\hline & \multicolumn{7}{c}{ Age (days) } \\
\cline { 2 - 7 } & 30 & 33 & 34 & 35 & 38 & 40 \\
\hline No. of rats & 4 & 4 & 4 & 10 & 5 & 4 \\
PGE-2 & $36 \pm 14$ & $46 \pm 12$ & $131 \pm 29 \dagger$ & $208 \pm 74^{*}$ & $144 \pm 17 \dagger$ & $19 \pm 9 \dagger$ \\
PGF-2 $\alpha$ & $20 \pm 4$ & $42 \pm 8$ & $38 \pm 18$ & $35 \pm 9$ & $31 \pm 9$ & $41 \pm 16$ \\
\hline
\end{tabular}

* Value significantly greater $(P<0.01$, Student's $t$ test $)$ than those of the other groups.

$\dagger$ Significantly different $(P<0 \cdot 01)$ from preceding group.

arachidonic acid levels are uniform during the process of maturation, although she (Carpenter, 1974) found 3-8 times more PGF-2 $\alpha$ in the immature rat testis than in adult tissue and the concentrations were at least 300 times higher than in our study. PGF- $\alpha$ has been measured in different parts of the genital tract of adult rats by Bartke \& Koerner (1974) who found, as we did, the highest values in the vas deferens and the lowest in testis and prostate, although the testicular and prostatic values reported were 80 and 10 times higher, respectively, than those found in our study. The most striking results concern the changes of PGE-2 and PGF-2 $\alpha$ in the vas deferens and the epididymis during maturation (Table 1). The PGE-2 content increased sharply in the vas deferens at 34-38 and 55-65 days and was also high in the adult rat. The PGF-2 $\alpha$ levels were always lower than those of PGE-2, and there was a significant decrease after 33 days. In the epididymis there was a marked and abrupt increase in the PGE-2 content between 34 and 38 days with a peak at 35 days (Table 2). Levels of PGF-2 $\alpha$ did not alter during this period.

Hib \& Caldeyro-Barcia (1974) have shown that the caput exhibits less marked and more irregular spontaneous contractions than the cauda epididymidis and that drugs such as epinephrine, norepinephrine and acetylcholine which markedly enhance the contractility of the cauda have no significant effect on caput motility. The PG content of the caput and cauda epididymidis during the critical period of maturation, the start of spermatogenesis in this strain of rat, was therefore examined (Table 3). The concentrations of PGE-2 were higher at 33-35 days than at 38-40 days in both parts of the epididymis and 4 times higher in the cauda than in the caput.

These results show that there is an age-dependent alteration of PGE-2 but not of PGF-2 $\alpha$ in the epididymis and vas deferens of the rat, even when spurious results caused by synthesis and degradation in vitro were prevented by the controlled methodology. The significance of the very high concentrations in the vas deferens is not immediately apparent but they are presumably concerned with the motility of spermatozoa and ejaculation. The sharp peak in PGE-2 levels in the epididymis, 
Table 3. The concentrations (mean \pm S.E.M.) of PGE-2 and PGF-2 $\alpha(\mathrm{ng} / \mathrm{g})$ in the caput and cauda epididymidis of the rat

\begin{tabular}{ccccccccc}
\hline & & \multicolumn{3}{c}{ Caput epididymidis } & & \multicolumn{3}{c}{ Cauda epididymidis } \\
Age (days) & No. of rats & PGE-2 & PGF-2 $\alpha$ & E-2:F-2 $\alpha$ & PGE-2 & PGF-2 $\alpha$ & E-2:F-2 $\alpha$ \\
\hline $33-35$ & 10 & $93 \pm 0$ & $35 \pm 11$ & $2 \cdot 6$ & & $347 \pm 23$ & $27 \pm 10$ & $12 \cdot 8$ \\
$38-40$ & 10 & $43 \pm 24$ & $44 \pm 15$ & $1 \cdot 0$ & & $175 \pm 17$ & $40 \pm 11$ & $3 \cdot 6$ \\
\hline
\end{tabular}

Each segment of tissue was frozen $135 \pm 15 \mathrm{sec}$ after death.

mainly in the cauda, at 35 days of age coincides with a peak in plasma FSH (Swerdloff, Walsh, Jacobs \& Odell, 1971; Negro-Vilar, Krulich \& McCann, 1973), the maturation of spermatozoa in the testis (Swerdloff et al., 1971), and the arrival of testicular fluid and spermatozoa in the epididymis (Setchell, 1970). Furthermore, a single i.v. injection of PGE-2 into male rats aged 30-35 days produces an increase of serum FSH (Sato, Jyujo, Iesaka, Ishikawa \& Igarashi, 1974). Further studies on the relationship between the levels of serum FSH and PGE-2 in the cauda epididymidis of 30-40-day-old rats are in progress.

We thank Dr B. P. Setchell for commenting on the manuscript. Partial support came from the Institut National de la Santé et de la Recherche Médicale, grant No. 75-40-37.

\section{References}

BARTKe, A. \& KoERner, S. (1974) Androgenic regulation of the concentration of prostaglandin $\mathrm{F}$ in the male reproductive system of rats and mice. Endocrinology 95, 1739-1743.

Carpenter, M.P. (1971) The lipid composition of maturing rat testis. The effect of $\alpha$-tocopherol. Biochim. Biophys. Acta 231, 52-79.

Carpenter, M.P. (1974) Prostaglandins of rat testis. Lipids 9, 397-406.

Carpenter, M.P., Manning, L. \& Wiseman, B. (1971) Prostaglandin synthesis in rat testis. Fedn Proc. Fedn Am. Socs exp. Biol. 30, 1081, Abstr.

Christ, E.J. \& VAN DORP, D.A. (1972) Comparative aspects of prostaglandin biosynthesis in animal tissues. Biochim. Biophys. Acta 270, 537-545.

Davis, J.R., Langford, L. \& KIRBY, K. (1970) The testicular capsule. In The Testis, Vol. 1, pp. 282-334. Eds A. D. Johnson, W. R. Gomes \& N. L. VanDemark. Academic Press, New York.

DeCuminsky, B.S. \& MerCuRY, O. (1971) The identification of prostaglandin $\mathrm{E} 1$ in rat seminal vesicle gland. Lipids 6, 278-280.

Dray, F., Charbonnel, B. \& Maclouf, J. (1975) Radioimmunoassay of prostaglandins $F \alpha, E_{1}, E_{2}$ in human plasma. Eur.J. clin. Invest. 5, 311-318.

Eliasson, R. (1959) Studies of prostaglandin occurrence, formation and biological actions. Acta physiol. scand. 46, Suppl. 158, 1-73.

ELLIs, L.C. (1972) Rat testicular prostaglandin synthesis and its relationship to androgen synthesis. Fedn Proc. Fedn Am. Socs exp. Biol. 31, 295, Abstr.

HaFs, H.D., Lous, T.M. \& Stellflung, J.N. (1974) Increased sperm numbers in the deferent duct after prostaglandin $F_{2 x}$ in rabbits. Proc. Soc. exp. Biol. Med. 145, 1120-1124.

Hib, J. \& CaldeYro-Barcia, R. (1974) Neurohormonal control of epididymal contraction. In Physiology and Genetics of Reproduction, pp. 111-116. Eds E. M. Coutinho \& F. Fuchs. Plenum Press, New York.

Jouvenaz, G.H., Nugteren, D.H., BeERThuis, R.K. \& VAN DORP, D.A. (1970) A sensitive method for the determination of prostaglandins by gas chromatography with electron capture detection. Biochim. Biophys. Acta 202, 231-234.

Maclouf, J., ANDrieU, J.M. \& DRAY, F. (1975) Validity of $P G E_{1}$ radioimmunoassay by using $P G E_{1}$ antisera with differential binding parameters. FEBS Letters 56, 273-278.

Negro-Vilar, A., Krulich, L. \& McCaNn, S.M. (1973) Changes in serum prolactin and gonadotropins during sexual development of the male rat. Endocrinology 93, 660-664.

SATO, T., JyUjo, T., IESAKa, T., IshikaWA, J. \& IgARAshi, M. (1974) Follicle stimulating hormone and prolactin release induced by prostaglandins in rat. Prostaglandins 5, 483-490.

SeTCHell, B.P. (1970) Testicular blood supply, lymphatic drainage and secretion of fluid. In The Testis, Vol. 1, pp. 101-218. Eds A. D. Johnson, W. R. Gomes \& N. L. VanDemark. Academic Press, New York.

SWERdloff, R.S., WALSH, P.C., JACOBS, H.S. \& Odell, W.D. (1971) Serum LH and FSH during sexual maturation in the male rat: effect of castration and cryptorchidism. Endocrinology 88, 120-128.

TAN, W.C. \& PrivetT, O.S. (1972) Analysis of prostaglandins in rat vesicular glands. Lipids 7, 622-624. 